\title{
Discourses of education and constitutions of class: public discourses on education in Swedish PBS television
}

Eva Reimers

\section{Linköping University Post Print}

\section{Tweet}

N.B.: When citing this work, cite the original article.

This is an electronic version of an article published in:

Eva Reimers, Discourses of education and constitutions of class: public discourses on education in Swedish PBS television, 2014, Discourse. Studies in the Cultural Politics of Education, (35), 4, 540-553.

Discourse. Studies in the Cultural Politics of Education is available online at informaworldTM:

http://dx.doi.org/10.1080/01596306.2013.871228

Copyright: Taylor \& Francis (Routledge) http://www.routledge.com/

Postprint available at: Linköping University Electronic Press http://urn.kb.se/resolve?urn=urn:nbn:se:liu:diva-107636 


\title{
Discourses of Education and Constitutions of Class - Public Discourses on Education in Swedish PBS Television
}

\author{
Drawing on post-structural perspectives and data from public discourses on \\ education in Swedish television, the paper investigates articulations of neoliberal \\ education discourse in opposition to and together with a discourse of equal \\ education. It then examines how class emerges and is made significant (as \\ economic subject positions and categories) in the framework of these \\ articulations. The analysis shows that the programs, in a complex way, articulate \\ and construct public education as simultaneously a private and a public good. \\ Class, as subject positions that point to different economic life trajectories, is \\ constituted as intersections of place, race, gender and school achievements.
}

Keywords: education in the media, educational discourses, education and class

\section{Introduction}

The Swedish welfare society has been renowned as an example of social engineering designed to create an equal society (see, e.g., Ball \& Larsson, 1989; Wolfe, 2000). This is also the case within public education. From the 1940s onward, public education has been seen as a means to compensate for differing class based prerequisites (Lundahl, 2002). This is the reason why Sweden has had a nine-year comprehensive primary school since the 1960s. However, since the beginning of the 1990s, the school system has experienced major changes. Instead of serving as an example of an encompassing comprehensive school aimed at offering an equal education for everybody, Swedish primary education has become market-driven. The former catchphrase "equal education for everyone" has been replaced by "free choice", and the notion that difference and competition — between schools and between students—will generate better educational results (Lundahl, 2002). This shift in focus and aim can be seen as a result of the 
hegemony of a neoliberal educational discourse (see e.g., Bunar, 2009; Dahlstedt \& Hertzberg, 2011), with a shift from education as a common good to education as a private good (Englund (1996; 2005). The question asked here is how this discursive shift is articulated in a public discourse and how this affects constitutions of class as categories and subject positions. How is the hegemony of the neoliberal educational discourse articulated? What happens to representations of inequalities in education when the dominant discourse abandons the focus on equal education for everyone in favour of meeting the needs and wishes of individuals? What happens to representations of classed positions when education policies change from focusing on advancing the common good to focusing on creating a competitive market?

\section{The significance of class in education}

The notion that class plays a significant role in education is by no means a new insight. A wealth of studies point to schools and education as classed contexts in which socioeconomic background is of considerable importance for how individuals succeed within the educational system (see e.g. Caldas, Bernier, \& Marceau, 2009; Carey, 2008; Croll, 2008; Willis, 1977). This research indicates that schools rather than neutralizing social differences serve as tools for dividing and sorting subjects. In discussing and researching class, I partly align with the tradition of Pierre Bourdieu, which employs a multidimensional concept of class in terms of different forms of capital (Bourdieu \& Passeron, 1990; Bourdieu, Broady, \& Palme, 1993; Olssen, 2004), but at the same time I believe there are good reasons to be cautious about using this conception of class. My reservation pertains to how research in this tradition tends to use a stable and unambiguous notion of class as its point of departure, thereby running the risk of stabilizing and enforcing stereotypical norms that facilitate marginalization and 


\section{E. Reimers}

exclusion (see e.g., Ambjörnsson, 2004; Lucey \& Walkerdine, 1999; Skeggs, 1997;

Walkerdine, Lucey, \& Melody, 2001). Instead I wish to propose a conception of class that allows us to question and criticize how classed positions are interpellated and made meaningful (Butler, 1995; Youdell, 2011). My perspective is similar to that of Gillborn (2010). In a study of representations of the white working class in Britain, Gillborn treats "working class" as a "shifting signifier", a concept akin to the discourse theory concept "floating signifier" (Laclau \& Mouffe, 1985). Class is hereby understood as an open concept rather than as a defined category. The difference between my perspective and that of Gillborn is that I do not presume the existence of a defined "working class" that can be represented in different or shifting ways. The point of departure for the present study is that definitions of class, and the significance of being positioned as belonging to a specific class, are part of a construction of class contingent on the context in which class is constituted and made meaningful. Class is thus not seen as an essential trait of individuals or as definite social categories defined by their position, role and function within the economy. Class is instead regarded as possible subject positions embedded in different discourses and discursive fields. This does not mean that economy is insignificant. Different positions entail orientations, or flight lines, which construct expectations as to what the individual or the group can or ought to be able to do (Ahmed, 2006). The consequences of how individuals and groups become classed are dire, as the discourses in which they become embedded circumscribe roles, possibilities and limitations within the economy. In this way, class delineates what it is possible to think and do within the boundaries of an assigned economic subject position. Furthermore, class is a relational category. Constitutions of class not only establish social distinctions, they also hierarchize them (Fiske, 1996, p. 65). In order to explore class in public educational discourses, I have asked questions such as: What signifies 
practices, places, categories, groups and individuals which are positioned as "problems"? What are the characteristics of "success" and "failure"?

\section{Consequences of the neoliberal educational discourse in Swedish education}

There is a large body of research showing that neoliberal ideology and discourses have permeated educational policies, reforms, and practices in most parts of the world (see, e.g. Ball, Goodson, \& Maguire, 2007; Biesta, 2009; Bunar, 2009; Buras \& Apple, 2005; Forsey, 2009; Giroux, 2003; Hartley, 2008; Harvey, 2005; Lindblad \& Popkewitz, 2004). In line with Ball (2006), one can argue that these neoliberal educational reforms are manifested in new forms of governance and new professional subjectivities for teachers, students and parents. Teachers have become providers of a commodityeducation - and students and parents are regarded as customers with equal prerequisites for making rational and well-informed choices (see also Hartley, 2008). This is also the case in Sweden. Three reforms in 1991-92 have been major measures in this direction. The first reform decentralized responsibility for the schools from the state to the municipalities (Prop. 1990/91:18). This was followed by the reforms allowing free school choice and independent schools (Prop. 1991/92: 95). This encompassed the decision on school vouchers, stipulating that $85 \%$ of the average cost to the municipality for each student should follow the students to their school of choice. This has created a quasi-market in which schools, both private and municipal have to compete for resources in the form of students and the ensuing vouchers (Lundahl, 2002). The positions of students and parents have hereby shifted from learners and guardians, to customers and economic assets. The positions of teachers have been changed from experts and teachers, to providers of a service.

In discussing education and class, Ball (2006, p. 34-35) has pointed to how the notion of school choices as choices made by rational and informed subjects 


\section{E. Reimers}

simultaneously totalizes and individualizes the parents and the students. Regardless of educational background, income, and social position, all parents are presumed to have the same prerequisites to make the best educational choices for their children. In this way, the neoliberal educational discourse tends to obfuscate and disregard the significance of both social categories and different social and material possibilities and prerequisites. Differences between schools and differences in how individual students perform on comparative tests are represented as the outcome of poor practices or bad choices, not as the consequences of differing contexts and preconditions.

The neoliberal school reforms can be seen as examples of the opposition between neoliberal reforms and the welfare society (Harvey, 2005). This is further highlighted by a research review of the consequences of the recent Swedish educational reforms (Skolverket, 2009). The report, published by The Swedish National Agency of Education, asserts that school results have declined and that the social background and social context of the individual student have become more decisive than they previously were (cf. Lundahl, 2002). Although debated, this critique has not influenced the reforms of the government or how public education is addressed in the media (see, e.g., Zaremba, 2011). The neoliberal educational discourses continue to be used, and thereby affirmed, as a foundation for public debates about the state of the Swedish schools.

\section{Constructions of hegemony - a poststructural perspective}

Although I, like many others (e.g., Benveniste, Carnoy, \& Rothstein, 2003; Plank \& Sykes, 2003), am critical of the neoliberal education reforms, I do not agree with the slightly conspiratorial explanation of the neoliberal hegemony offered by Hursh and Henderson (2011). In line with post-Marxist (Laclau \& Mouffe, 1985; Mouffe, 2005) and post-humanist (Barad, 2007; Sellers \& Gough, 2010) theories, I propose a more complex understanding of how hegemonies are constructed and maintained. In line with 
these theories hegemonies are regarded as relational, open and constantly simultaneously stabilized and subverted. This perspective calls for a deconstructive analysis that is open to multiple readings of the data. Furthermore, the neoliberal educational discourse, like all discourses, is repeated intersectionally together with other discourses, both other educational discourses and discourses of knowledge, rationality, success, nature and so forth. One aim of this article is therefore to delineate how these discourses work together in the constitution of class within the discourse of education.

\section{Media discourses on education}

The data on which the present study is based consist of television programs. The study differs in this respect from most studies of hegemonic discourses on education, which employ policy documents, bills and legislation as data. Education has become a prevalent topic in the media, especially in connection with elections or pressconferences that present new policy measures (Franklin, 2004; Gewirtz, Dickson, \& Power, 2004; MacMillan, 2002). The body of studies on education in the media is however conspicuously small. Most of the studies in the field focus press media (see e.g., Franklin, 2004; MacMillan, 2002; Thomas, 2003; Wiklund, 2006), although there are scant studies which also include broadcasted media (Warmington \& Murphy, 2004), or who looks at "popular media" in press, broadcast, literature and movies (Meskill, 2007; Weber \& Mitchell, 1995). Most of the studies on education and media claim that the media influence education policies. There is however a slight disagreement in the direction of influence. Franklin (2004) and Gewirtz et.al., (2004) claim that politics influence the media in order to set the agenda and gather support for changes in education policies, whereas for example Thomas (2003) takes the opposite position claiming that media representation of education influence politics. The common denominator for these opposing positions is the pivotal position of the media in the 


\section{E. Reimers}

creation of hegemony. I agree that media do have a role in constituting public notions on education; I am however less certain about the causes and effects of media representations. Even if public articulations of problems, remedies, results, aims and reforms with, for and in compulsory education partake in the formation of a hegemonic discourse in education, public discourses of education are not solely reproducing dominant norms and ideology. Instead I see them as parts of a contingent assemblage of norms, notions, practices, and materialities that together construct the phenomenon of public education, an assemblage in which the hegemony of the neoliberal discourse encounters resistance and therefore is subverted and changed (Barad, 2007; Laclau \& Mouffe, 1985). It is when hegemonic conceptions meet resistance, when actors point to failures and problems within the neoliberal educational practices and policies, that boundaries, possibilities, and alternative interpretations and positions are made possible.

Furthermore, differing from the aforementioned studies, the present paper is based on data from a continuous and regular PBS television program on education. The study can hereby be seen as a study of a continuous public conversation about education in which the political aims and interests are less clear cut, or are made deliberately more salient, than in the studies above.

\section{Method}

The study looks at how events or issues connected to education are represented in television programs, not at the events or issues as such. The main questions pertain to how different norms and discourses are assembled and articulated so as to represent specific issues in specific ways. The analysis is methodologically inspired by critical discourse analysis (Fairclough, 2003; Matheson, 2005) in the sense that it is focused on how images, sound, and talk articulate issues, actors, and social categories in terms of hierarchies and power, and in relation to each other. Another source of inspiration is 
posthumanist theory, which prompts the analysis to focus on how discourses work rather than on intentions from specific actors or what the discourses mean (Jackson \& Mazzei, 2012). The interest is in detailing intersecting representations of domination and subordination, and in how categorizations of different subject positions intersect, and to what effect (cf. Gillborn, 2010 p. 5). The results of the analysis is not considered as "the truth" about the neoliberal educational discourse and class in Sweden, or in the data investigated. Other readings are possible. The fact that others may perceive these programs differently does not, however, preclude the existence of the discursive constructions that I point to, though different views may perhaps partly question their significance.

The data are 26 episodes from 2008-2010 from the Swedish PBS television program Skolfront, which presents itself as a show that carries out investigative reporting and airs exciting debates about "the largest workplace in Sweden, the schools" (www.ur.se/skolfront). It has approximately 12 programs every year. The most common format is to address two topics in each program. These are elaborated and illustrated by reports, each one followed up with a debate or discussion.

\section{Results}

The analysis of the programs shows that the neoliberal educational discourse and the discourse of equal education are intertwined rather than constituted as oppositions in these programs, and that this evokes shifts and subversions of both these discourses. It furthermore suggests that the focus on individual choice, which is a signifier of neoliberalism, opens the door to a constitution of class where race, place, gender, socioeconomic position and agency work together with concepts such as school performance, achievement, rowdy students and truancy. 


\section{E. Reimers}

The way in which the neoliberal education discourse is articulated in the framing (Entman, 1993) of public discourses about education can be illustrated by the topics chosen for four political debates in Skolfront prior to the 2010 election. The topics were: lack of discipline in the Swedish schools (11 April 2010), the free school choice (15 April 2010), grades and assessments (22 April 2010), and why Swedish students are falling behind in the rankings in international league tables (2 May 2010). All of these topics originate from the neoliberal educational discourse (Ball, 2006; Buras \& Apple, 2005). The hegemony is, however, ambiguous, because the topics are constituted together and in opposition with the discourse about a comprehensive school and equal education. It is these opposing discourses that together constitute what can be described as a discursive educational assemblage.

\section{How to make sense of social mobility and education?}

The opposition between the two discourses is a connecting thought throughout the Skolfront programs. One program employs a research review on the consequences of the reforms of the 1990s as its point of departure to discuss the gradual dismantling of the comprehensive school (22 March 2009). In another program, the host refers to ranking figures from international league tables asking "Why do Swedish students do worse?" (6 October 2009). One of the discussants in the studio refers to the report above (Skolverket, 2009) and argues that low results and increased segregation are a consequence of the neoliberal school reforms. The host and one of the debaters-a

social democrat — both claim that these reforms have made the social background of the student more important than it used to be. The right-wing discussant states that free choice is always a good thing and declares that "we should not go back to the old comprehensive school where a clever student could get stuck in a bad school" (6 October 2009). The debaters can be seen as articulating two different conceptions of 
equal education. The social democrat bases his arguments on the notion that the schools should be a means to decrease social and economic differences in society at large. The right-wing politician focuses on being able to transgress social boundaries through individual choice. Her conception of equal education was the topic of a report in a program the following season (4 March 2010). This report follows two teenagers-a girl and a boy—who live in a suburb of Stockholm with low average salaries and a high percentage of immigrants. In contrast to most of their peers, we are told by the voiceover, these students have made use of the free school choice and are attending a private independent school in the center of the city, where the majority of students define themselves as "Swedish" and come from middle- or high-income families. The report shows how the two students on their daily commute pass by the local school they used to attend. The students tell that they changed school because they wanted to learn more. The contrast between the two schools is enhanced by images of an inner city school with newly furnished rooms in an office building, and images of a rundown grey concrete school building in the suburb. The principal of the latter says that loss of high achieving and motivated students is having negative effects on the students who remain. This is affirmed by former classmates who state that they miss the students who left, because they encouraged others to study. The report turns to a researcher who asserts that parents and students in most cases base school choices on the status of the neighborhood the school is in and the ethnic background of the majority of the students. He claims that multicultural schools do not lose students because of bad results or poor pedagogy, but because of how society values and assesses the students in these schools. This is affirmed by the boy in the report who states that a major reason for changing schools was that there were so many immigrants in his former school that his mother was worried he would not learn "proper Swedish". The researcher recognizes that free 


\section{E. Reimers}

choice has facilitated "individual integration" for those who have the cultural resources to choose another school than the local, but that it has also increased segregation between schools on a structural level. But the report does not only reveal the opposition between neoliberal educational discourses and discourses about equal education. It also elucidates how social mobility for some entails getting stuck in subordinated social and economic positions for others. From the perspective of the neoliberal educational discourse, this is not a problem, because every student has the option to leave for another school. From the perspective of equal education, it is problematic because it stabilizes and increases social and economic inequalities. At the same time as some individuals can use free school choice to transgress classed positions, the same classed positions are enforced both in the sense that they serve as a foundation for the choices (both what to leave behind and what to choose instead), and in the sense that the gap between different classed positions is increased.

\section{Winners, losers and class}

The increased social differentiation between schools subverts the former ideal of a comprehensive school. This is an obvious challenge to the notion of equal education for everyone. The frequent reports in Skolfront about students whose prospects are limited rather than enhanced by the neoliberal reforms can thus be understood as resistance to and arguments against the neoliberal school reforms. This is not equivocal, however, as some reports point to students who are given better prospects to develop thanks to the recent reforms. In two of these reports, the focus is on students who, owing to their above-average talents, had difficulties enjoying, learning and developing in a school focused on equal education. The first is a report on "elite classes" (23 November 2008), which is a new phenomenon in contrast to the former ideology of a comprehensive school. The report follows a student who states that it is great to finally find some 
challenges in mathematics because the teaching and the assignments in his former school were far too easy. This report can be seen as a reiteration of the statement above that prior to the reforms "clever students were stuck in bad schools" (6 October 2009). Talented students are consequently constituted as a category that has benefited from the neoliberal educational reforms. A similar contention is found in a report about so-called "hyper-intelligent students" (21 March 2010). The report tells the story of an 11-yearold boy. At the beginning of the film, he is playing with a dog outside a large house by a lake. Later we see him inside the house in a spacious kitchen. The boy and his mother are shown in close-ups recounting how he learned to read at the age of 3 and a half, how he was far ahead of his peers already in kindergarten, and how he lost interest in school because he found the assignments trivial. The mother recounts that he was eventually tested and found to have an exceptionally high IQ. The voice-over constitutes the local public school as incapable or unwilling to accommodate its' practices to the individual needs of the hyper-intelligent student by recounting that the family eventually "had enough". When the boy was to begin 4th grade, they enrolled him in a commercial independent school who could meet his needs. He started in the 6th grade, studies English at the 8th grade level, and Spanish at the 9th grade level. Like the talented students above, this hyper-intelligent boy benefits from a school that differentiates between students.

These representations of the talented and "hyper-intelligent" students are in stark contrast to the representations of truant and/or rowdy students. The same program that had the report on the hyper-intelligent boy above also addresses truancy. Although both categories - truants and the "hyper-intelligent" - are said to have needs the schools have difficulties meeting, they are represented very differently. In the juxtaposition of these two categories, it becomes evident that it is taken for granted that it is not because they 


\section{E. Reimers}

are "hyper-intelligent" that truants are bored and cut school. This has more to do with character. This is enforced by an image of a teenage girl who is seen blowing out cigarette smoke through her pierced lips. She is walking outside dressed in black tights, a black top with a plunging neckline, a black leather jacket, and long henna-dyed hair. This is in line with similar other representations of students who are used to illustrate "problems", such as in a report about a school that has launched a program directed at getting truants back to school (24 February 2008), and in a program with two reports on rowdy students (15 February 2009). The students in these reports are also seen smoking and dressed in baggy sweat pants. Several are overweight, and the girls have died hair, heavy makeup, and plunging necklines. The visual representation of the truant girl can therefore be seen as signaling "youth in trouble". The girl recounts that when she began to cut class in $8^{\text {th }}$ grade, she simultaneously started smoking, drinking, scrawling and shoplifting. The report shifts to a photo of her when she was around 8 years old. This is followed by three more photos that construct her gradual decline. In the second, she has heavy makeup, and in the final photo she is wearing heavy metal apparel with a dog collar with rivets, a net undershirt, and a white painted face. Together with her account of drinking, smoking, stealing, and cutting school, the images construct the girl as being at risk, or in the position "asocial". At the end of the report, we are informed that she is now doing fine and has continued to upper secondary school.

Although both the truant girl and the hyper-intelligent boy are constituted as "deviating" or "problematic," their juxtaposition reveals the classed aspect of the report. The problem of the truant girl is what she might be doing when she is not in class, while the problem of the hyper-intelligent boy is that he finds school too easy. Although there is some mention of the risk that school could become so boring for the hyper-intelligent that they might decide not to attend, it is clear that in the first case the problem is 
primarily the truant girl and in the second case the problem is the insufficient school system. This difference can also be attributed to class. Although both students recount that they have found school boring, they are constituted as different in terms of their resources, status and prospects. The girl is represented as depressed and risking becoming asocial, and thereby constitutes a possible burden on society. In the case of elite classes and hyper-intelligent students, the risk is losing possible assets for society.

\section{Gender, class and place}

Even if the neoliberal educational discourse is focused on individuals and rarely points out categories of students, it is a common phenomenon in most countries that boys are increasingly represented as losers in the school system (see, e.g., Hinnerich, Höglin, \& Johannesson, 2011; Lam et al., 2012; Lucey, Walkerdine, 1999, Watson, 2011; Younger \& Warrington, 2008). This is the topic of three programs (30 March 2008, 22 November 2009, 25 March 2010). In two of these, the problem is elucidated by examples from places that can be seen as obsolete or the home of losers in modernity (30 March 2008, 22 November 2009). The first report is about boys in a rural and scarcely populated municipality in the far north of Sweden. The school is introduced as the school with the largest difference in Sweden between boys' and girls' school performance. Although not explicitly articulated, the report contributes to the construction of problematic and low-performing boys, not only in terms of gender, but also in terms of place (cf. Gulson, 2008; Massey, 2005). The boys are represented as taciturn, and as prioritizing their snow-scooters and other leisure-time activities. This can be seen as typical of how the working class - or under-class — is often characterized as choosing the "here and now" in favor of actions directed at the future (Ball, 2003; Oria et al., 2007). The stereotypical notion of "the silent northern and rural male" whose main interest is hunting and fishing hereby contributes to the construction of asocial behavior. The similarity between this 


\section{E. Reimers}

construction and the aforementioned portrayal of the truant girl is disinterest both in school work and in investing in one's own future. This is salient in terms of how the voice-over and images work together in the report. When the voice-over speaks about low-achieving boys, the image is of boys in a classroom, dressed in baggy sweat-pants, hoodies and big baseball caps, who are playing around and not paying attention to the teacher. In the report, these indifferent boys are contrasted with ambitious and attentive girls. Their teacher offers a culture- and class-based explanation of why so many boys do not seem to care about school. She states that, in the past, the boys in the area did not need an education because they went directly from school to work in the mines. Now the mines are closed and the municipality has high unemployment rates, and the attitude is that education is useless because there are no jobs to go to anyway. This construction of boys in the northern and rural part of Sweden not only reiterates and draws on gender norms, but also on norms about unskilled manual labour in contrast to skilled nonmanual work, and the rural in opposition to the urban. In this report, the construction of the initial "problem," explaining why boys generally show poorer school achievement than girls do, intersects with class and place. This not only shifts the notion of lowperforming boys from boys in general to rural working-class boys, but also creates a classed division between boys and girls, where girls in general are constituted as hierarchically above boys. This hegemonization of boys and girls can be seen in relation to the program on truants, which was focused on a girl, as well as the reports on elite students and the hyper-intelligent, where the examples were boys. In this report, there is no room for truant girls or ambitious boys. All girls are represented as ambitious and all boys as disinterested. The difference in focus between a less valued "here and now" and a more valued orientation towards the future is made manifest by talk about the girls, who are expected to move south after graduation. Class-mobility is thus equated with 
spatial mobility, such that social and geographical spaces intersect.

\section{Race, class and place}

In the programs, losers in the educational game are not only situated in rural areas.

Other places that are repeatedly constructed as problematic and as inhabited with lowachieving students, are the deprived urban neighborhoods with a significant number of working-class and minority residents. One example is the report referred to above that portrayed two students who had used free school choice to create better conditions for their future (4 March 2010). Another example is a report about a municipality in which students are bussed from a district characterized by a high percentage of inhabitants with a non-Swedish background to a school situated in an area characterized by a homogeneous Swedish population (28 October 2010). The report is based on the presumption that students from the "Swedish" area achieve better in school than students with "foreign backgrounds." The latter are hereby represented as a threat to the status and good assessment of the school. According to the voice-over, the reason for the bussing was that the school in the ethnically diverse area was in need of restoration. Because there were not enough students to fill the places at the ethnically homogeneous school, the authorities found it convenient to send the students with non-Swedish background there. The report constructs an opposition between "immigrant-dense" and "affluent", which simultaneously equates immigrants with "poor" and the affluent with "Swedish." The images of the two districts, which are said to be only a six-minute bus ride apart, construct difference in terms of housing, population density, race, and economic resources. This is underscored by the description of the districts as "different worlds." The district of the students who are bussed is designated as a "problem area" where "half of the population has a foreign background." The articulation of "problems" together with "foreign background" implies causality. The other district is described as 


\section{E. Reimers}

affluent and with "... few inhabitants with a foreign background." Here there is no mention of the possibility of "problems." The two places are depicted as opposites, where economy, race, place, and school achievements together construct hierarchically dichotomous categories. A major difference between how the students in the two areas are represented concerns agency. The students from the affluent area are by the voice over talked about as "choosing to leave" or "choosing to remain." The students from the ethnically diverse area are said to be "bussed," "assigned," and "moved". The affluent, "Swedish," and fair-skinned students who live in private homes are thus constructed as agents who make choices, whereas the impoverished, "immigrant," darkskinned students who live in apartment houses are represented as being subjected to measures imposed by authorities. In this way, the report constitutes a hierarchical difference between those in a position to make use of their free choice and those who are not in a position to choose.

The notion that race (immigrant) and place (immigrant and low education) are likely to lead to low achievement on the part of students and the school is also repeated in a report on homework (27 November 2008). It is from a school situated in an urban neighborhood with a high percentage of immigrants, but in contrast to what is expected from a school dominated by students with non-Swedish background, it is represented as a successful school. The students reach the national goals and do well on national exams. The report and the ensuing debate constitute an opposition, but also intersection of the neoliberal educational discourse and the discourse on equal education. The peculiar thing about this school is not only its unexpected good results, but the absence of homework. The argument for this, according to the principal of the school, is that not all children have equal prerequisites to receive assistant with their homework. In order to create equal opportunities for all students to reach the goals of the curriculum, the 
school therefore refrains from homework but offers "study yards" that students can attend after school hours and receive individual support and assistance in their studies. The report is followed by a debate between the minister of education (right wing) and a member of parliament (socialist). Despite the documented good results in the school in the report, the minister is appalled by the idea of not practicing homework. He says that homework is a good way of extending the time of teaching and learning. It teaches children to be responsible and is a means to involve parents in their children's education. When the MP asks the minister if there isn't a difference in parents' ability to assist their children, his answer is "Of course we'll give special help to those who need it, but let's not disqualify all Swedish parents". The minister thus constructs some parents as capable, the norm, and others as incapable, showing that his argument presumes and is based on the notion of well-educated parents with high proficiency in Swedish and the time and space to assist their children. The practice of home-work is thus constituted as having a value in itself, regardless of learning outcomes and increased segregation between students.

\section{Discussion}

The present study reveals that although the recent educational reforms in Sweden reiterate a neoliberal educational discourse, this discourse is not as hegemonic as one might expect. Like all hegemonies, the neoliberal educational discourse is constituted by counter-hegemonies, in this case primarily by a discourse on equal education for everyone. In the television programs about education that form the data for the article, these two discourses delineate each other's' boundaries, and each new articulation changes the discourse somewhat. It is, for example, the discourse of equal education that enables the repeated critique that neoliberal education reforms have increased the differences between both students and schools. Furthermore, when this critique is 


\section{E. Reimers}

articulated, there are no denials of the legitimacy of the claim that the schools ought to give equal prerequisites for everybody. Instead the proponents of the neoliberal ideology claim that if students and parents made the right choices and if the schools worked differently, the aim would be fulfilled. In this way, the neoliberal discourse in some instances incorporates the notion of equal education. There is correspondingly no, or very little, critique of using league tables and national tests to assess the quality of a school voiced by those who advocate equal education. Although there are differences concerning the causes of and remedies for schools that are constituted as lowperforming, there seems to be no disagreement as to how to assess whether or not a student or a school is successful (cf. Benjamin 2003). In this way, the neoliberal educational discourse comes to harbor and includes the notion of equal education, and the discourse of equal education comes to harbor and includes the notion of learning in terms of measurable "facts", and the significance of comparing test results from different countries. The significance of equal education is simultaneously articulated and displaced when it is recontextualized within the neoliberal discourse (cf. Englund, 2005). Instead of establishing that the task of the schools is to give all students the prerequisites to accomplish a good education, the meaning shifts to offering all individual students the possibility to choose an education that will create prerequisites for them as individuals to get a good education and achieve social mobility. It is a matter of equal rights, not being offered equal prerequisites.

The notion of the individual as being capable of and responsible for making educational choices that will maximize her/his future prospects is fundamental to the Swedish neoliberal educational discourse. It is on the basis of this notion that the free school choice reform has been implemented, and it is a notion that is salient in the present study as well. The analysis above indicates that the entanglement of the two 
educational discourses contributes to a specific understanding of classed positions. The deconstruction of how losers and winners, in terms of schools, categories and individuals, are constituted in the programs disrupts the neoliberal contention of equal possibilities to make informed choices. Not all schools, categories or individuals are constituted as being endowed with equal possibilities to choose. In the data presented here, different conditions for schools, categories and individuals are rarely constituted in terms of over-, middle- and working-class. By deconstructing how some schools, categories and individuals are represented as winners, losers or problems, the study reveals constructions of class in which race, place, gender and socio-economic conditions are intertwined, such that the schools and the students are-despite the neoliberal emphasis on the individual—attributed not only different status but also different subject positions in terms of future prospects and trajectories (cf. Bunar, 2009). These attributions are based on students" position in relation to "the Swedish", where and how they live, their gender and their socio-economic situation. Although some individuals are represented as using free school choice to transgress classed positions, this does not subvert social hierarchies because stereotypical classed positions (race, place, gender, class) serve as a foundation for choices concerning both what to leave behind and what to choose instead. Representations of schools and students in stereotypical and hierarchal ways can be seen as not only enforcing classed subject positions, but also as potential subversion of the neoliberal emphasis on the individual and the notion of equal opportunities to make informed choices. In addition to race, place, gender and socio-economic position, agency comes forward as a signifier of class. In several programs, schools and individual students who are represented as evidence of the value of neoliberal education reforms are depicted as agents who chose something other than the expected or the mainstream, and these choices are constituted 


\section{E. Reimers}

as the basis of their success. Correspondingly, schools and students who are represented as not performing are often constituted as passive, and as subjects of the actions of others rather than as agents. In this way, agency becomes intertwined with race, place, gender, and socio-economic positions in a way that reveals that not all students, not even within the neoliberal education discourse, have the same prerequisites to make choices that will ensure them a successful future. This is not however unequivocal, their subordinated future prospects are simultaneously constituted as of their own choosing, as a consequence of their individual lack of (or bad) choice.

Although the data for the present study are situated and limited, it is important to point out that descriptions and debates on education are not innocent. Accounts of goals, achievements, problems, crises, and necessary measures to improve education interpellate subjects and groups into different positions, or as different economic subjectivities, where they are assigned different roles within the economy (Martinsson, 2006). Although these positions are to some extent open and not totally determined, they nonetheless delimit and point to very different life trajectories for different students, both as individuals and as categories. The difference in emphasis between the neoliberal educational discourse and the educational discourse on equal education for everyone entails an economical opposition concerning how to distribute and share the economic resources of a society.

In offering education to all students, one can either recognize the fact that students - due to place, race, gender, income, etc. - are assessed differently and given different opportunities within public education as a social problem that needs to be addressed, or one can choose to follow the neoliberal path and turn a blind eye to how students and schools are classed. Choosing the former implies critically exploring how 
access to education, rather than individual circumstances, creates different prerequisites for different subjects (cf. Biesta, 2009).

\section{References}

Ahmed, S. (2006). Queer phenomenology: Orientations, objects, others. Durham: Duke University Press.

Ambjörnsson, F. (2004). I en klass för sig: Genus, klass och sexualitet bland gymnasietjejer [In a class of their own. Gender, class and sexuality among upper secondary school girls]. Stockholm: Ordfront.

Ball, S. J. (2003). Class strategies and the education market: The middle classes and social advantage. London: Routledge Falmer.

Ball, S. J. (2006). Education policy and social class: The selected works of Stephen J. Ball. London; New York: Routledge.

Ball, S. J., Goodson, I., \& Maguire, M. (2007). Education, globalization, and new times. Abingdon, Oxon: Routledge.

Ball, S. J., \& Larsson, S. (1989). The struggle for democratic education: Equality and participation in Sweden. New York: Falmer P.

Barad, K. M. (2007). Meeting the universe halfway: Quantum physics and the entanglement of matter and meaning. Durham, N.C. ; London: Duke University Press.

Benjamin, S. (2003). What Counts as 'Success'? Hierarchical discourses in a girls' comprehensive school. Discourse: Studies in the Cultural Politics of Education, 24(1), 105-118.

Benveniste, L., Carnoy, M., \& Rothstein, R. (2003). All else equal: Are public and private schools different?. New York: Routledge.

Biesta, G. (2009). Good education in an age of measurement: On the need to reconnect with the question of purpose in education. Educational Assessment, Evaluation and Accountability, 21(1), 33-46.

Bourdieu, P., Broady, D., \& Palme, M. (1993). Kultursociologiska texter (4 ed.) [Texts on the sociology of culture]. Stockholm ; Stehag: B. Östlings bokförl. Symposion.

Bourdieu, P., \& Passeron, J. (1990). Reproduction in education, society and culture (2nd ed.). London: Sage. 


\section{E. Reimers}

Bunar, N. (2009). När marknaden kom till förorten: Valfrihet, konkurrens och symboliskt kapital i mångkulturella områdens skolor [When the market came to the suburb. Choice, competition and symbolic capital in schools in multicultural areas]. Lund: Studentlitteratur.

Buras, K. L., \& Apple, M. W. (2005). School choice, neoliberal promises, and unpromising evidence. Educational Policy, 19(3), 550-564.

Butler, J. (1995). Contingent foundations: feminism and the question of "postmodernism". Critical encounters., 213-232.

Caldas, S. J., Bernier, S., \& Marceau, R. (2009). Explanatory factors of the black achievement gap in Montreal's public and private schools: A multivariate analysis. Education and Urban Society, 41(2), 197-215.

Carey, D. (2008). Improving education outcomes in Germany (Working papers No. 611). Brussels: OECD Economic Department.

Croll, P. (2008). Occupational choice, socio-economic status and educational attainment: A study of the occupational choices and destinations of young people in the British household panel survey. Research Papers in Education, 23(3), 243-268.

Dahlstedt, M., \& Hertzberg, F. (2011). Skola i samverkan: Miljonprogrammet och visionen om den öppna skolan. [Schools in cooperation. The million program and the open school] Malmö: Gleerup.

Englund, T. (1996). Utbildningspolitiskt systemskifte?. [A system shift of educational politics]. Stockholm: Hls.

Englund, T. (2005). The discourse on equivalence in Swedish education policy. Journal of Education Policy, 20(1), 39-57.

Entman, R. M. (1993). Framing: Toward clarification of a fractured paradigm. Journal of Communication, 43(4), 51-58.

Fairclough, N. (2003). Analysing discourse: Textual analysis for social research. New York: Routledge.

Fiske, J. (1996). Media matters: Race and gender in U.S. politics (Rev ed.). Minneapolis: University of Minnesota Press.

Forsey, M. (2009). The problem with autonomy: An ethnographic study of neoliberalism in practice in Australian high school. Discourse: Studies in the Cultural Politics of Education, 30(4), 457-469. 
Franklin, B. (2004). Education, education and indoctrination! Packaging politics and the three 'Rs'. Journal of Education Policy, 19(3), 255-270.

Gewirtz, S., Dickson, M., \& Power, S. (2004). Unraveling a 'spun' policy: A case study of the constitutive role of 'spin' in the education policy process. Journal of Education Policy, 19(3), 321-342.

Gillborn, D. (2010). The white working class, racism and respectability: Victims, degenerates and interest-convergence . British Journal of Educational Studies, $58(1), 3-25$.

Giroux, H. A. (2003). Selling out higher education. Policy Futures in Education, 1(1), 179-200.

Gulson, K. N. (2008). Urban accommodations: Policy, education and a politics of place. Journal of Education Policy, 23(2), 153-163.

Hartley, D. (2008). Education, markets and the pedagogy of personalisation. British Journal of Educational Studies, 56(4), 365-381.

Harvey, D. (2005). A brief history of neoliberalism. Oxford: Oxford University Press.

Hinnerich, B. T., Höglin, E., \& Johannesson, M. (2011). Are boys discriminated in Swedish high schools? Economics of Education Review, 30(4), 682-690.

Hursh, D. W., \& Henderson, J. A. (2011). Contesting global neoliberalism and creating alternative futures. Discourse: Studies in the Cultural Politics of Education, 32(2), 171-185.

Jackson, A. Y., \& Mazzei, L. A. (2012). Thinking with theory in qualitative research: Viewing data across multiple perspectives (1st ed.). New York, NY: Routledge.

Laclau, E., \& Mouffe, C. (1985). Hegemony \& Socialist Strategy. London: Verso.

Lam, S., Jimerson, S., Kikas, E., Cefai, C., Veiga, F. H., Nelson, B., et al. (2012). Do girls and boys perceive themselves as equally engaged in school? The results of an international study from 12 countries. Journal of School Psychology, 50(1), 77-94.

Lindblad, S., \& Popkewitz, T. S. (2004). Educational restructuring: International perspectives on traveling policies. Greenwich, Conn.: Information Age Pub.

Lucey, H., \& Walkerdine, V. (1999). Boy's underachievement: Social class and changing masculinities. In T. Cox (Ed.), Combating educational disadvantage (pp. 37-51). London: Falmer.

Lundahl, L. (2002). Sweden: Decentralization, deregulation, quasi-markets - and then what? Journal of Education Policy, 17(6), 687-697. 


\section{E. Reimers}

MacMillan, K. (2002). Narratives of social disruption: Education news in the british tabloid press. Discourse: Studies in the Cultural Politics of Education, 23(1), 2738.

Martinsson, L. (2006). Jakten på konsensus: Intersektionalitet och marknadsekonomisk vardag [The pursuit for consensus. The everyday life of intersectionality and market economy]. Malmö: Liber.

Massey, D. B. (2005). For space. London: Sage.

Matheson, D. (2005). Media discourses. Maidenhead: Open University Press.

Meskill, C. (2007). Through the screen, into the school: Education, subversion, ourselves in the simpsons. Discourse: Studies in the Cultural Politics of Education, 28(1), 37-48.

Mouffe, C. (2005). On the political. London: Routledge.

Olssen, M. (2004). Culture and learning: Access and opportunity in the classroom. Greenwich, Conn.: Information Age Pub.

Oria, A., Cardini, A., Ball, S., Stamou, E., Kolokitha, M., Vertigan, S., et al. (2007). Urban education, the middle classes and their dilemmas of school choice. Journal of Education Policy, 22(1), 91-105.

Plank, D. N., \& Sykes, G. (2003). Choosing choice: School choice in international perspective. New York: Teachers College Press.

Proposition 1990/91:18. Ansvaret för skolan [The responsibility for the school]. Utbildningsdepartementet, Stockholm.

Proposition1991/92: 95. Om Valfrihet Och Fristående Skolor [On choice and independent schools]. Utbildningsdepartementet, Stockholm.

Sellers, W., \& Gough, N. (2010). Sharing outsider thinking: Thinking (differently) with Deleuze in educational philosophy and curriculum inquiry. International Journal of Qualitative Studies in Education (QSE), 23(5), 589-614.

Skeggs, B. (1997). Formations of class and gender: Becoming respectable. London: Sage.

Skolverket. (2009). Vad påverkar resultaten i svensk grundskola? Kunskapsöversikt om betydelsen av olika faktorer [What influences the results of the Swedish compulsory school?]. Stockholm: Fritzes.

Thomas, S. (2003). 'The trouble with our schools': A media construction of public discourses on Queensland schools. Discourse: Studies in the Cultural Politics of Education, 24(1), 19-33. 
Walkerdine, V., Lucey, H., \& Melody, J. (2001). Growing up girl : Psychosocial explorations of gender and class. Basingstoke; New York, N.Y.: Macmillan; New York University Press.

Warmington, P., \& Murphy, R. (2004). Could do better? Media depictions of UK educational assessment results. Journal of Education Policy, 19(3), 285-299.

Watson, A. (2011). Not just a 'boy problem': An exploration of the complexities surrounding literacy under-achievement. Discourse: Studies in the Cultural Politics of Education, 32(5), 779-795.

Weber, S., \& Mitchell, C. (1995). That's funny, you don't look like a teacher!. London; Washington D.C.: Falmer Press.

Wiklund, M. (2006). Kunskapens fanbärare: Den goda läraren som diskursiv konstruktion på en mediearena [The standard bearers of knowledge. The good teacher as a media construction on a media arena]. Örebro: Örebro Universitet.

Willis, P. E. (1977). Learning to labour: How working class kids get working class jobs. Farnborough: Saxon House.

Wolfe, A. (2000). Whose keeper: social science and moral obligation. Berkeley: University of California Press.

Youdell, D. (2011). School trouble: Identity, power and politics in education. Abingdon, Oxon; New York, NY: Routledge.

Younger, M., \& Warrington, M. (2008). The gender agenda in primary teacher education in England: Fifteen lost years? Journal of Education Policy, 23(4), 429-445.

Zaremba, M. (2011). Hem till skolan [Back to school]. Natur \& Kultur. 